解説 Explanation

\title{
三菱重工業の舶用ディーゼル機関開発を支える実験・解析技術“
}

\author{
石田裕幸** 赤川裕 和***
}

1. はじめに

エンジンで起こっている現象は複雑で，それにかか わる実験・解析技術も多岐にわたっている，燃焼に関 連する現象では, 吸入される空気の流動, 燃料噴霧挙 動，空気との混合による動的挙動，それに引き続く燃 焼，燃焼室壁面での熱伝達というように物理的そして 化学的な現象が複合して進行している.燃焼室外では, ピストンリング・ライナや軸受の潤滑の現象がある.

高効率・低公害・高信頼性のための技術開発では, これらの現象が計画通りに起きているかを確認するこ とが必要である. そのためは図 1 に示すような各種現 象の数值解析技術とこれらを支える実験技術が非常に 重要である. 本報では，三菱重工業の舶用ディーゼル 機関開発に適用されているこれらの実験・解析技術を 紹介寸る.

\section{2. 筒内流動の実験と解析}

ディーゼルエンジンで高い熱効率を得るためには， 燃料が筒内の限られた空気と効率的に混合して短い時 間で完全に燃焼するとともに，燃焼後の排ガスが効率 よく排出されることが重要である.このための実験と 解析技術につき述べる.

大型 2 サイクル舶用ディーゼル機関では，シリンダ ライナの下部に掃気ポートが設けてあり，空気はシリ ンダ中心に向かってある角度を持って流入することに よりシリンダ内に旋回流を発生させる ${ }^{1)}$.

図 2 に筒内流動の基礎試験装置を示す。試験装置は 縮尺 2 分の 1 の実機形状のモデルで，排気弁下流から 吸引して流れを形成している．筒内全体の流速分布を 計測する手法として，掃気室で混入したトレーサ粒子 をレーザ光により光らせてその移動速度から流速を算

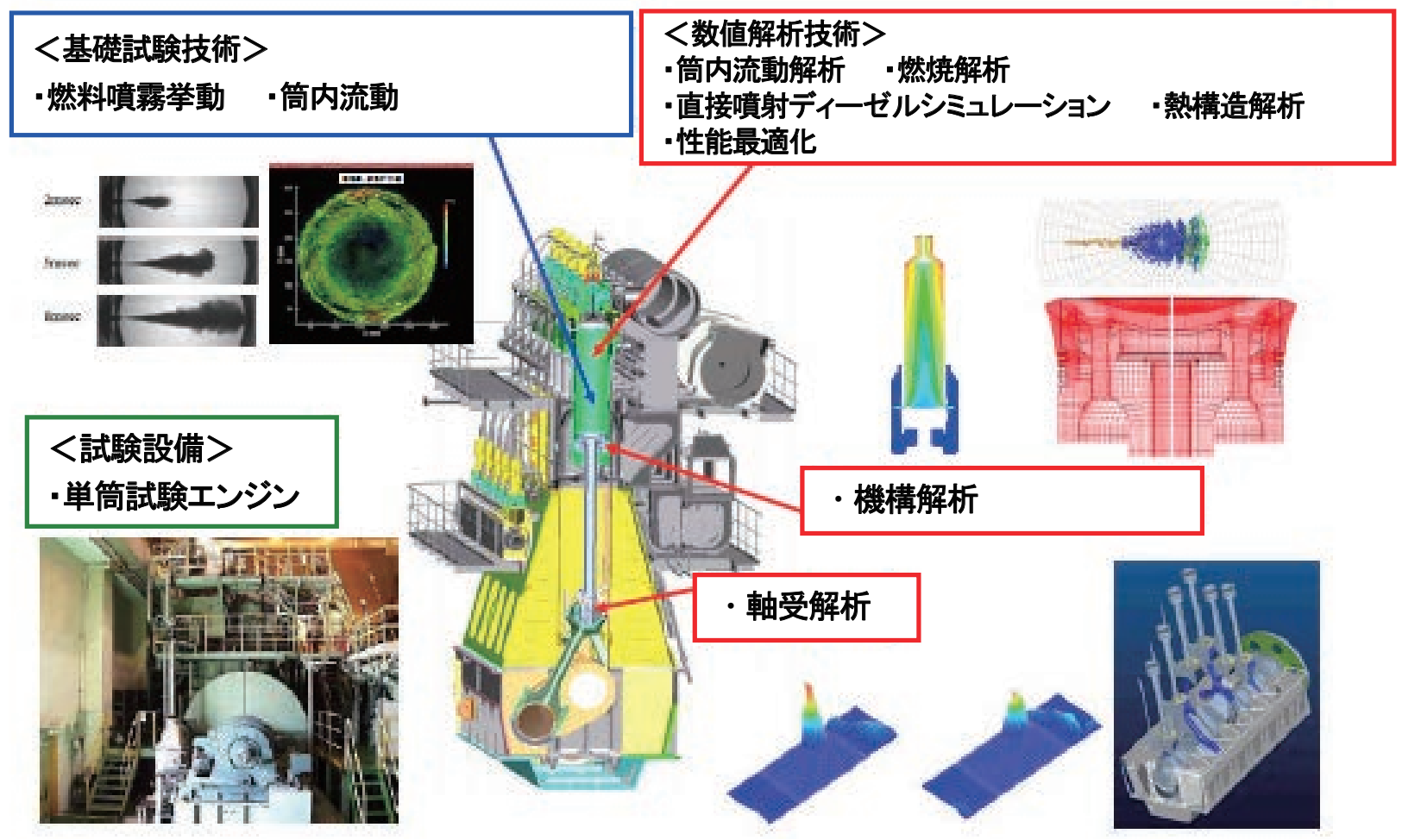

図 1 舶用ディーゼル機関開発の実験・解析技術

\footnotetext{
*原稿受付 平成 22 年 8 月 20 日

**正会員 三菱重工業株式会社

$* * *$ 三菱重工業株式会社
} 
出する粒子画像流速計測を行っている.

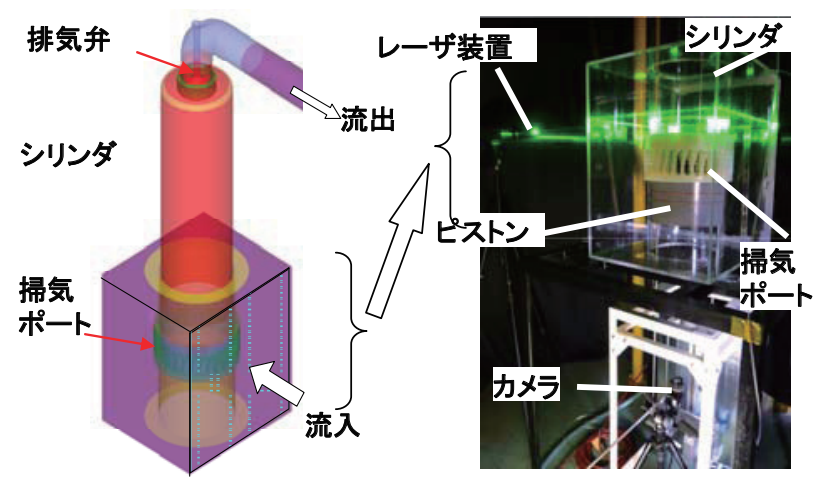

図 2 筒内流動の基礎試験装置

燃燒後の $\mathrm{CO}_{2}$ を含む筒内ガスは掃気期間中に効率よ く排出されて新気と入れ替わる必要がある。これを実 験的に確認寸るのは容易でないため, 筒内流動の解析 が重要で，図 3 に示すような掃気室から排気集合管ま での解析モデルを作成し, 筒内ガス温度や, 濃度分布 を評価している，図4はシリンダ中心からの距離と旋 回流速の関係を示したもので，最適な乱流モデルを使 用することで解析結果が実測值とよく一致することが わかる。

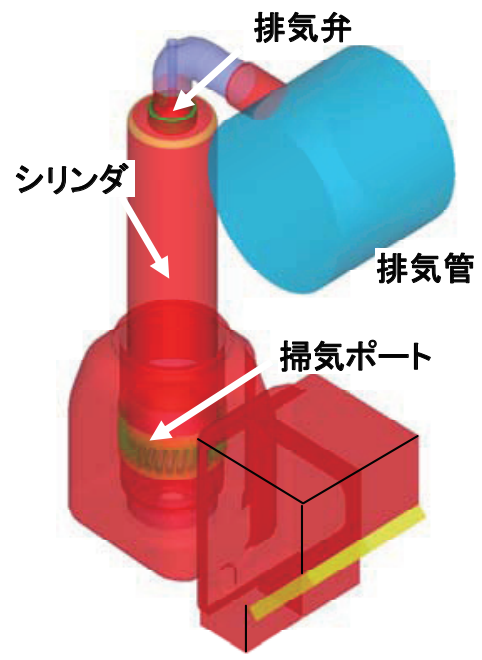

図 3 筒内流動解析モデル

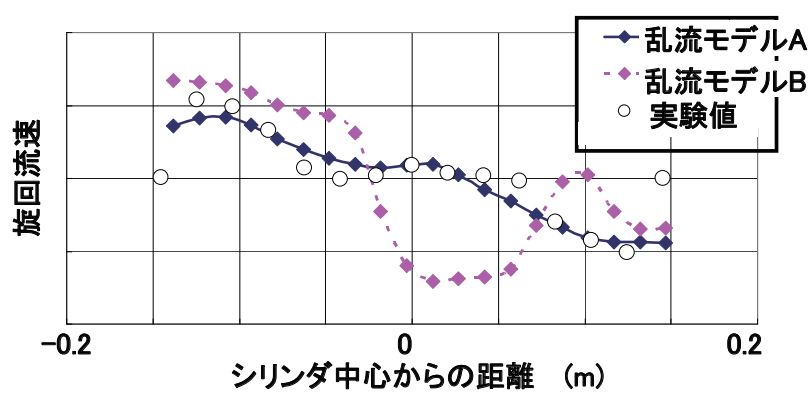

図 4 筒内流動観察結果との比較

\section{3. 燃料噴霧挙動の実験}

近年では数值解析によりディーゼル燃焼の熱発生, NOx 生成の予測が高効率・低排ガス化の研究開発に適 用されている．短い計算時間で精度の高い予測を行う ためには, 燃焼のベースとなる燃料噴霧挙動を把握し, 適切に解析モデルに折り込む必要がある ${ }^{2)}$. 図 5 は燃 料噴霧挙動観察の基礎試験について説明したもので, 実機シリンダ内のガスを模擬した定容観察容器内の燃 料噴霧の高速度撮影写真とそれから読みとった噴霧先 端の到達距離と噴霧の拡がり角を示している．画像の 左側に噴射ノズルがあり，時間とともに噴霧の到達距 離が伸びてゆく，容器内には窒素ガスの約 5 倍の高密 度ガス 6 フッ化硫黄を使用して室温で試験することで, 0.5 1. $0 \mathrm{MPa}$ の圧力で実機シリンダ内のガス密度を模 擬している. 噴霧観察結果を数值解析結果と比較寸る ことにより解析モデルの検証を行い解析の予測精度向 上を図っている.

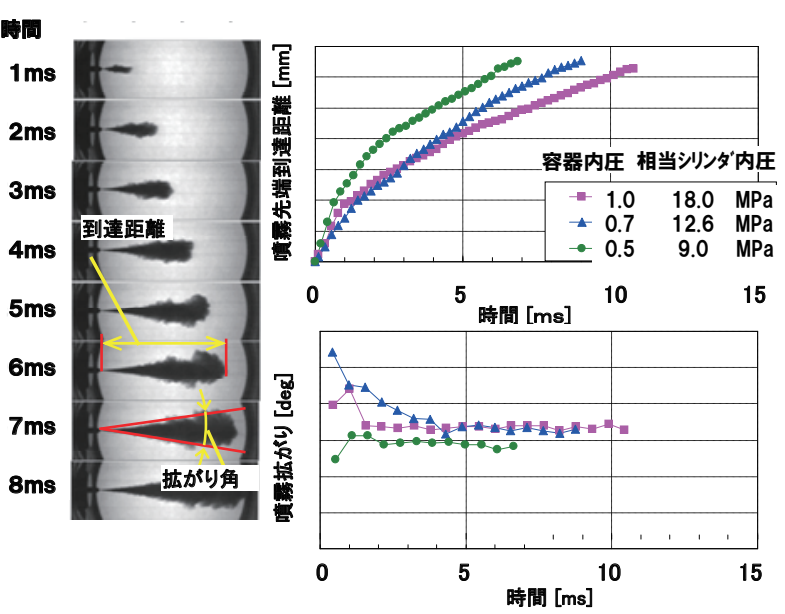

困 5 燃料噴霧挙動観察の基礎試験

\section{4. 燃焼解析}

燃焼解析では，筒内流動解析結果を受けて燃料噴需 の分裂・蒸発，着火から燃焼に至る燃料之空気の物理 的・化学的反応を解析して熱発生やNOX 等の化学成分 発生の予測を行う。図 6 は燃焼解析の手順を示したも ので，筒内流動解析結果から，筒内ガス温度・圧力分 布，流速・乱流エネルギー分布，および然焼ガス濃度 のデータの引渡しを承けて，ピストン，カバー，排気 弁で囲まれた燃焼室空間のメッシュ分割したモデルを 作成し，筒内圧力，熱発生率，火炎温度分布，NOx 分 布を計算する。図 7 は噴霧観察基礎試験結果と解析結 果を比較を示したもので，解析は実測によく一致して いるがわかる. 図8は火炎温度分布, NO 分布の計算結 果を示したもので，燃焼室空間の高温部分に対応して 
No が発生していることがわかる. 図 9 は燃料と空気の 条件を変化させた場合の実測と解析による NOx と燃費 率を示したもので, 実機の NOx, 燃費率の増減傾向が 実測と解析で良く一致していることがわかる.
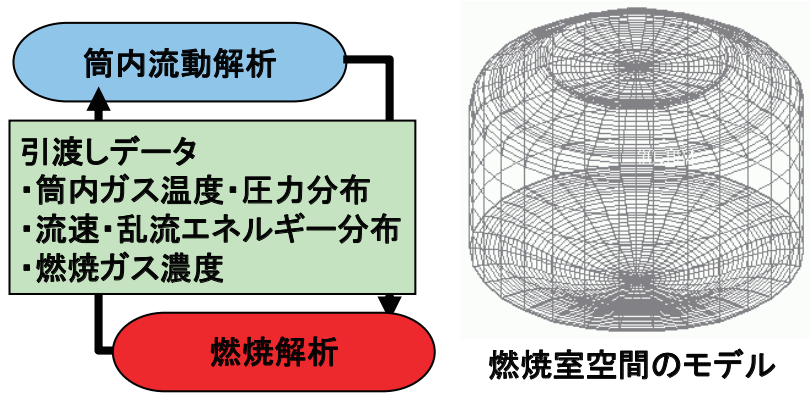

図6 燃焼解析手順

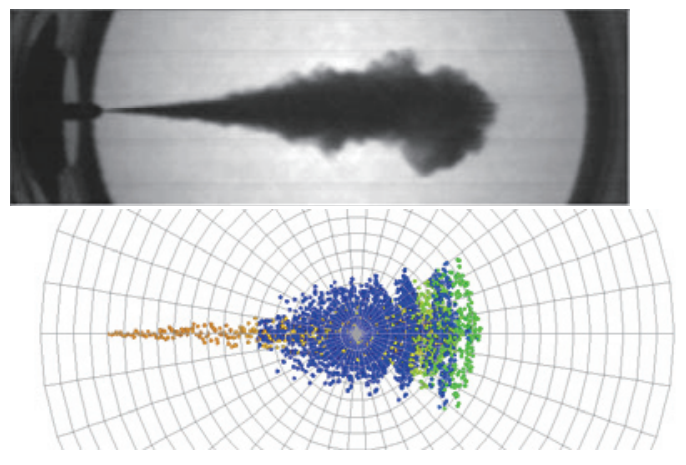

図 7 噴霧観察結果との比較

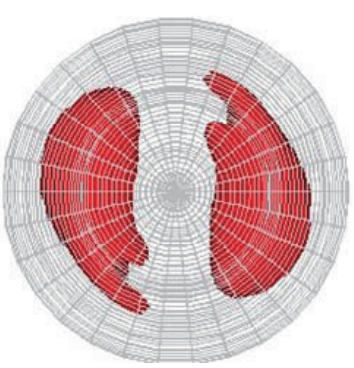

（a）火炎温度等值面

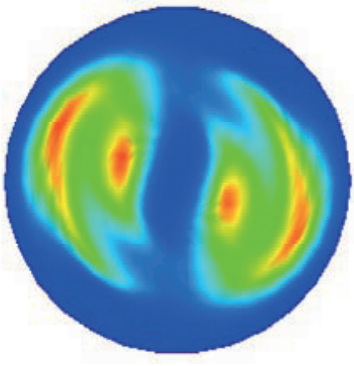

(b) NO 分布予測
図 8 火炎温度等值面と N0 分布の解析結果
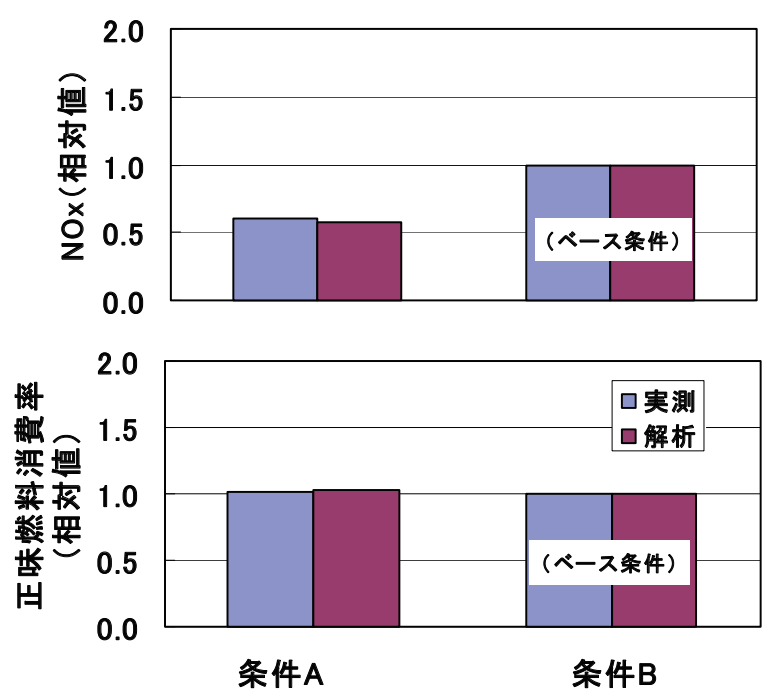

図 9 Nox および然費率の変化傾向予測結果

\section{5. ピストンリング・ライナの解析}

ピストンリングは，潤滑油の油膜をシリンダライナ との間に形成しながら摺動してシリンダ内の高圧のガ スがピストンとシリンダの隙間から漏れるのを防止す るシール機能を果たしている.このピストンリングの スカッフとは，エンジン内部において，潤滑不良や圧 力過大によりシリンダ壁の油膜が切れ, シリンダライ ナの金属面直接接触して損傷する現象である。ピスト ンリングのスカッフリスクを小さく寸るためには，十 分な油膜厚さを確保したうえで面圧 P とピストン速度 $\mathrm{V}$ を掛けた值である接触 $\mathrm{PV}$ 值を下げることが重要であ る.

リング・ライナの解析フローを図 10 に示す. 手順と しては，まず，機構解析によりピストンおよびピスト ンリングの挙動を解析する. 次に, 各時間ステップで リング間ガス圧力計算し，リングの挙動とガス圧を入 力条件として, リングとライナ間の油膜厚さ，接触面 圧を評価する. このための解析モデルを図 11 に示す. 1 シリンダ分のピストン, ピストン棒, クロスヘッド, 連接棒, クランクを機構解析用にモデル化し, ピスト ンリングは弾性体としリング溝と接触の境界条件とす ることで， 3 次元での挙動を評価可能な 6 自由度を持 ってモデル化している．ピストンリング摺動面は，粗 さ接触を考慮した 2 次元油膜挙動を評価している. 解 析結果を図 12 に示寸. リング適正化により PV 值が低 減されることがわかる. 


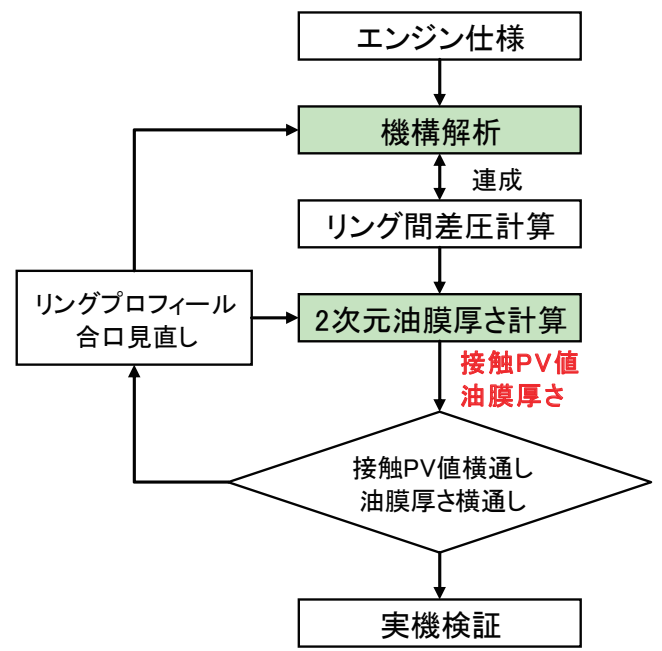

図 10 リング・ライナの解析フロー

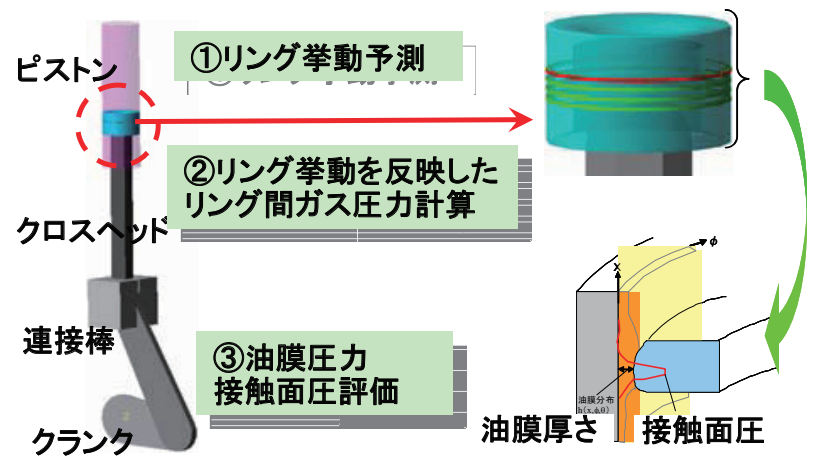

図 11 リング・ライナの解析モデル

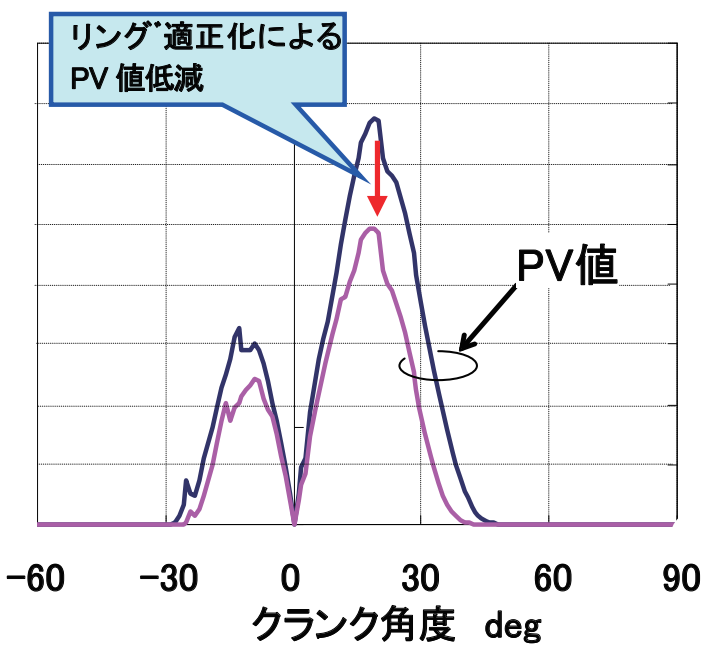

図 12 PV 值の解析結果

\section{6. 軸受解析}

エンジンの高出力化に伴い，軸受はますます過酷な 運転条件で使用されるようになってきている。このた め，変動荷重軸受を対象に弾性流体潤滑理論（EHL： Elastic Hydrodynamic Lubrication）を適用した軸受 特性手法を開発して舶用ディーゼル機関の評価に適用 している ${ }^{3)}$.

主軸受の解析フローを図 13 に示す.解析の手順とし ては，まず，クランクシャフト，隔壁をFEMによりモ デル化して岡性を計算し，多軸受解析にて軸受荷重お よび軸傾きを計算する. その結果をインプットとして, 3 次元 EHL 解析をすることで軸受面の油膜圧力と油膜 厚さを評価する.このための解析モデルを図 14 に示す. 多軸受解析ではクランク軸系全体をバネーマスモデル 化，クランクシャフトおよび隔壁の一部は FEM モデル 化して岡性を算出, 算出した岡性多軸受解析と 3 次元 EHL 解析に反映させる. 3 次元 EHL 解析では弾性変形 と油の履歴を考慮したモデル化を実施している．油膜 圧力の解析結果を図 15 に示す.軸受メタル形状の最適 化により油膜圧力が低減できることがわかる.

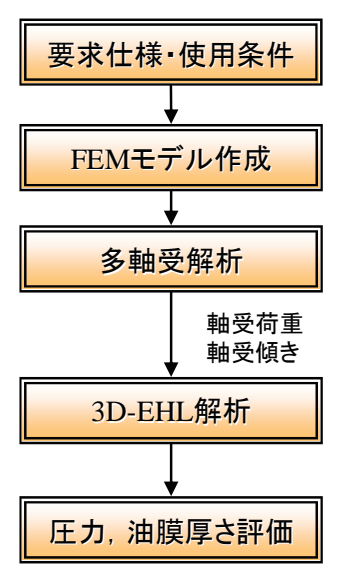

困 13 主軸受の解析フロー

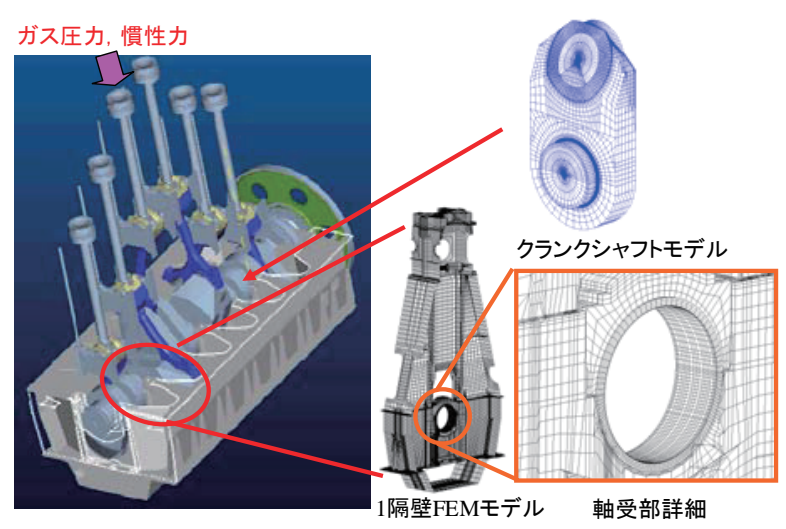

図 14 主軸受の解析モデル 


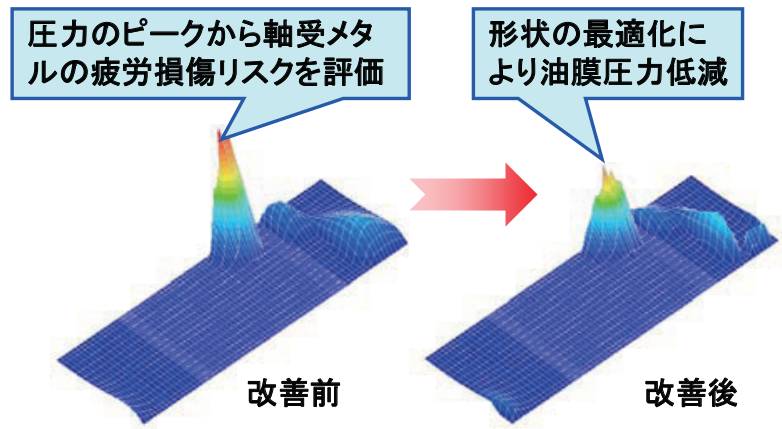

図 15 主軸受油膜圧力の解析結果

\section{7. 単筒試験エンジンによる検証}

舶用ディーゼル機関の各種システム開発においては, 単筒試験エンジンを使用して，多シリンダ実機に適用 する前に各種システムの検証試験を実施している．具 体的な試験内容は掃気ポート最適化試験, 燃焼室仕様 最適化試験, EGR 性能評価試験, リング・ライナ信頼 性評価試験等である. 表 1 に単筒試験エンジンの諸元, 図 16 に外観を示す.

一例として，燃焼排ガスの一部を掃気中に再循環さ せる EGR 試験時の排ガス NOx 計測結果を図 17 に示す. EGR により 50\%程度の NOx 低減効果が得られることが 確認された. 図 18 に燃焼性能試験結果を示す. EGR に よる燃料消費率のペナルティは小さい. EGR を行うこ とによりばいじんを含む排ガスが過給機コンプレッサ， エアクーラ，掃気室を通過するので，これらを含む掃 排気系の信頼性対策を行えば，EGR が舶用ディーゼル の NOx 規制への有効な対策となりうることを示すもの である。

表 1 単筒試験エンジン諸元

\begin{tabular}{|l|l|}
\hline シリンダ径 & $330 \mathrm{~mm}$ \\
\hline ストローク & $1400 \mathrm{~mm}$ \\
\hline 定格出カ & $763 \mathrm{~kW}$ \\
\hline 定格回転数 & $3.03 \mathrm{~s}^{-1}$ \\
\hline 正味平均有効圧 & $2.10 \mathrm{MPa}$ \\
\hline 平均ピストン速度 & $8.5 \mathrm{~m} / \mathrm{s}$ \\
\hline
\end{tabular}

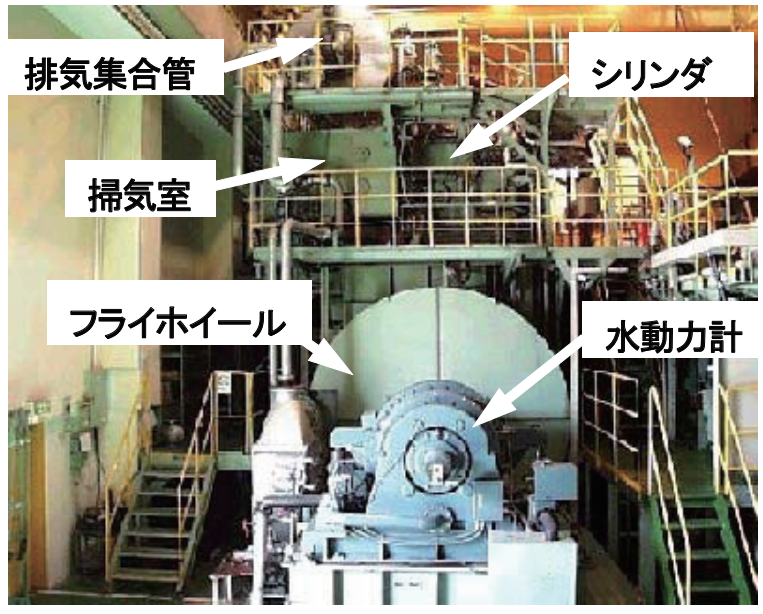

図 16 単筒試験エンジン外観

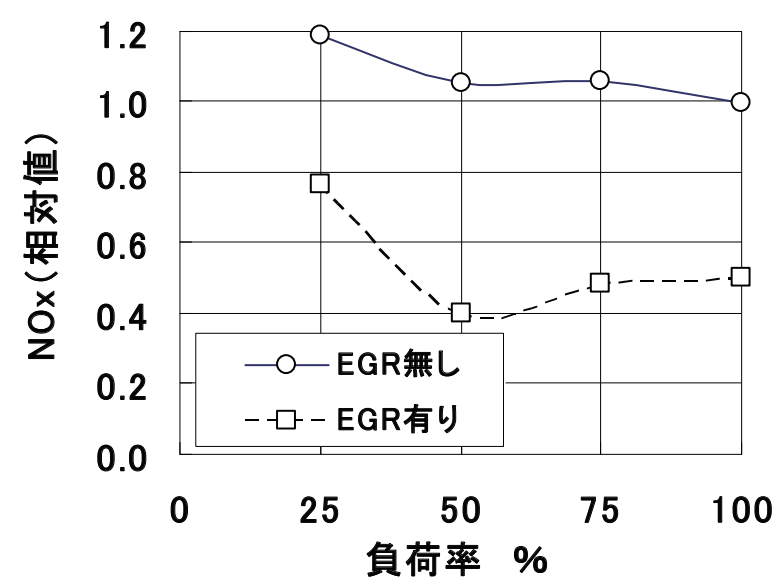

困 17 EGR 時の排ガス NOx 計測結果

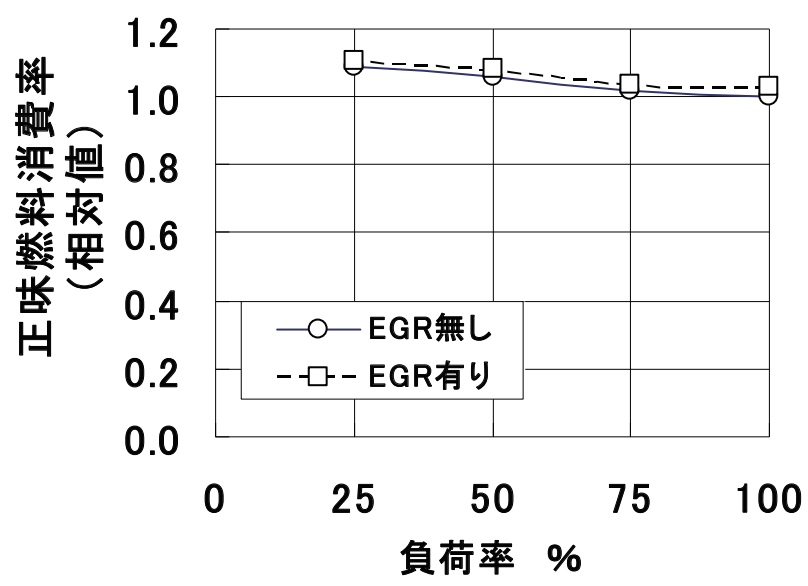

図 18 EGR 時の燃焼性能試験結果 


\section{8. 環境対応ディーゼル機関の開発}

当社は 2004 年に，環境対応ディーゼル機関 “UEC Eco-Engine” を開発した ${ }^{4}$. 燃料噴射系, 排気動弁系, 始動系, シリンダ注油系を中心に従来の機械式から電 子制御化への変更を行った。

図 19 に示寸ように, 燃料噴射系のパイロット電磁弁 はメイン電磁弁とサブ電磁弁からなり, これらの作動 タイミングに時間差をつけることで然料噴射モードを 制御することが可能である。これにより，初期の燃焼 温度を低下させ，従来機関に対して NOx 排出量の低減 が可能となる。

また，図 20 に示すとおり，エンジン負荷，大気条件 と燃料性状に応じて燃料噴射タイミングと噴射パター ンを最適化することにより，ローエミッションモード を選択した場合, 従来力ム式と比較して, 燃費一定の まま Nox を約 10～15\%低減することが可能である. 一 方，燃費優先モードでは NOx 排出量は一定のまま，燃 費を 1〜2\%改善することも可能である.
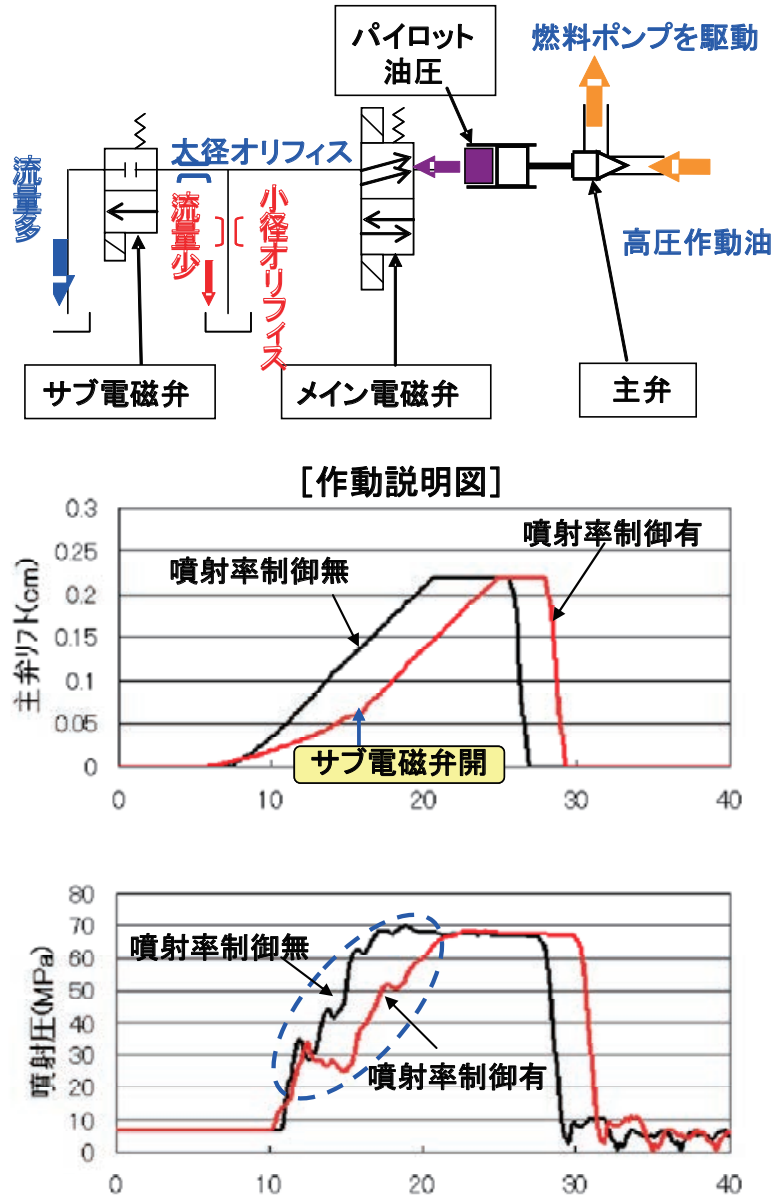

指令信号からのクランク角度(deg)

図 19 燃料噴射率の制御

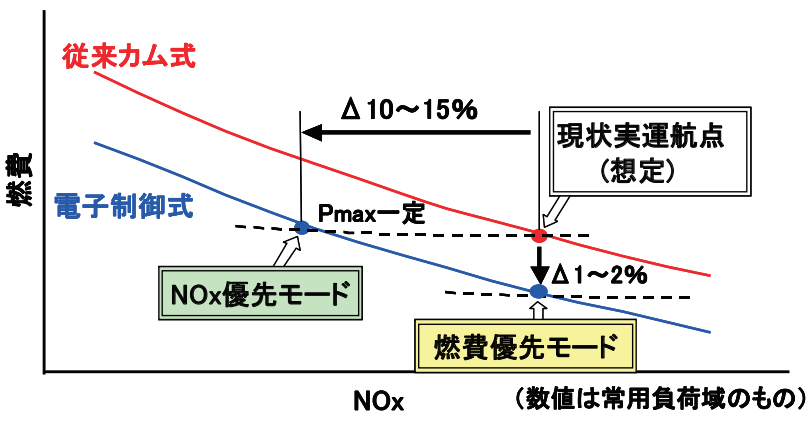

図 20 燃費と NOx 排出量の改善

9. おわりに

舶用ディーゼル機関からの NOx 排出に対する IMO の 2 次規制が 2011 年の建造船から施行され，2016 年以 降さらに規制が強化される見込みである。また，地球 温暖化防止の点から $\mathrm{CO}_{2}$ 排出削減に貢献するエンジン の熱効率向上に対するニーズも高まっている．これら に対応する高性能・低公害・高信頼性の舶用ディーゼ ル機関の役割は今後ますます重要になってくると考え られる．電子制御技術とともに、ベースとなる実験技 術，解析技術のさらなる充実を図ってゆく.

\section{参考文献}

1)若月ほか 1 名, 日マリ学誌, 44-2(2009),59-66.

2) Y. Imamori , et al., SA E, 2009-01-1937.

3)牧野ほか 1 名, 三菱重工技報, 38-6(2001),292-295.

4)杉原, 日マリ学誌, 39-12(2004),855-860.

\section{著者紹介}

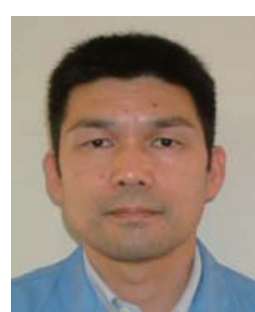

石田裕幸

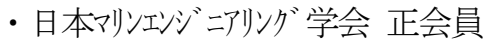

- 1964 年生.

· 三菱重工業株式会社.

- 九州大学大学院.

- 内燃機関.

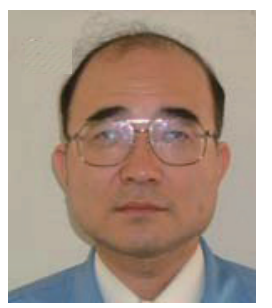

赤川 裕和

・ 1958 年生.

・ 三菱重工業株式会社.

- 東京大学大学院.

- 内燃機関. 